\title{
JPEB
}

Jurnal Penelitian Ekonomi dan Bisnis, 1 (1), 2016, Hal: 70 - 85

http://www.jpeb.dinus.ac.id

\section{ANALISIS PERBEDAAN PERSEPSI PSIKOLOGI KEUANGAN ANTARA PRIA DAN WANITA DI KOTA BATAM}

\author{
Novendy Arifin ${ }^{1 *}$ dan Robin ${ }^{2}$ \\ ${ }_{1}^{12}$ Fakultas Ekonomi, Universitas Internasional Batam \\ J1. Gajah Mada, Baloi-Sei Ladi, Batam 29442, Indonesia \\ *Corresponding Author : novendyarifin@gmail.com
}

Diterima: November 2015; Direvisi: Januari 2016; Dipublikasikan: Maret 2016

\begin{abstract}
Nowadays, the use of money and people's daily activity are two inseparable things. In term of using money and gender differences, men and women both have unique financial behavior. This is because of the nature of psychology that exists in individuals which cause differentiation on each. This research aims to examine the gender differences related to financial psychology. This research uses purposive sampling method. The object of this research is working people and/or people with working experience in the City of Batam. 471 out of 500 questionnaires were obtained and can be used. The result of this research shows that women are tend to feel more anxious when it comes to money and always meet difficulty on decision making related to money usage. In the other hand, men seem to always consider money as priority, the power of life, symbol of success and comparative tool.
\end{abstract}

Keywords: Gender; Financial Behavior; Financial psychology

\section{ABSTRAK}

Dalam melakukan aktifitas keseharian tidak pernah lepas dari penggunaan uang. Ada hal yang cukup unik dalam menggunakan uang (financial behavior) jika melihat dari dua gender, pria dan wanita. Hal unik ini didapatkan dari sifat psikologi yang ada di internal individu yang menyebabkan cara penggunakan antar individu ini berbeda. Penelitian ini bertujuan untuk meneliti perbedaan antar gender di Kota Batam dalam melihat psikologi keuangan. Sebanyak 500 set kuesioner yang disebarkan dengan tingkat pengembalian 471 kuesioner dengan objek penelitian masyarakat Kota Batam yang sedang atau pernah bekerja. Metode pemilihan sampel yang digunakan adalah dengan metode purposive sampling. Hasil penelitian yang didapatkan adalah wanita lebih merasa khawatir saat ditanya mengenai keuangan yang dimiliki dan cenderung lebih sulit untuk mengambil keputusan untuk menggunakan uang atau sebaliknya karena perasaan akan takut ketika mengeluarkan uang sementara pria dalam melihat keuangan cenderung mengedepankan uang dalam hidup, kekuatan hidup, simbol kesuksesan, alat standar perbandingan, dan cenderung menimbun kekayaan.

Kata Kunci: Jenis Kelamin; Perilaku Menggunakan Uang; Psikologi Keuangan 


\section{PENDAHULUAN}

Perkembangan investasi secara regional, nasional, maupun internasional seperti saat ini tetap mendapatkan perhatian dari pemerhati ekonomi dunia karena selain disisi untuk menjaga keseimbangan posisi keuangan dalam sebuah institusi, hal ini juga dapat mempengaruhi terhadap tingkat kemajuan ekonomi di dalam suatu negara. Pemutusan untuk melakukan sebuah investasi didasari oleh pelaku ekonomi pribadi, tetapi perilaku diantara gender (Pria dan Wanita) kerap memiliki perbedaan tergantung dengan kondisi lingkungan internal dan eksternal. Durvasula dan Lysonski (2010) dalam hasil penelitian yang berjudul "Money, Money, Money - How do Attitudes Toward Money Impact Vanity and Materialism? - the Case of Young Chinese Consumers" menemukan jika pola perilaku penggunaan uang oleh individu didasari dari tingkat kegengsian atau juga dikarenakan pengaruh oleh orangtua.

Beberapa litelatur menjelaskan jika penggunaan keuangan tidak hanya didasarkan oleh pengaruh eksternal individu tetapi faktor psikologi juga turut menentukan pengunaan uang tersebut. Adanya faktor psikologi dapat mempengaruhi hasil investasi yang akan dicapai. Selain dikarenakan oleh faktor psikologi, beberapa studi penelitian mengungkapkan jika perbedaan gender juga memiliki perbedaan pola pemikiran dalam hal keuangan, seperti halnya studi yang dilakukan Barber dan Odean (2001) memberikan bukti dari hasil penelitian yang dikaji menemukan jika kaum pria lebih berani mengambil resiko (risk seeker) dalam melakukan investasi dibandingkan dengan kaum wanita (risk averter), hal ini disebabkan faktor psikologis dimana pria merasa lebih percaya diri dibandingkan oleh wanita yang cenderung merasa pesimis. Penelitian yang dilakukan oleh Hibbert et al., (2007) menjelaskan bahwa meskipun strata pendidikan yang dimiliki oleh tiap individu selaras atau sederajat bukan berarti tingkat pengetahuan yang dimiliki dalam hal keuangannya juga sama sebab peneliti tersebut menemukan jika kaum wanita lebih cenderung menghindari resiko yang kemungkinan akan terjadi kedepannya.

Handi dan Mahastanti (2012) dalam jurnalnya yang berjudul "Perilaku Penggunaan Uang: Apakah Berbeda Untuk Jenis Kelamin dan Kesulitan Keuangan" menganalisis mengenai perilaku keuangan para investor yang menanam modalnya di Pasar Modal di Kota Salatiga, Semarang, Jawa Tengah, menunjukkan sebagian besar jumlah investor didominasi oleh pria karena didapatkan jika diri pribadi pria adalah sebagai penopang ekonomi keluarga dan dengan berinvestasi berarti berani mencoba hal baru. Berbeda dengan responden wanita yang cenderung lebih memilih berhati-hati dalam menggunakan uang, wanita lebih menyetujui untuk menghindari resiko termasuk perihal dalam berinvestasi, tetapi wanita lebih percaya diri bila memiliki sejumlah uang yang lebih besar dari yang dimiliki oleh sekitar, hal ini dikarenakan oleh tingkat pesimis yang dimiliki, dan wanita menjadikan uang sebagai alat standar ukuran untuk membandingkan sesuatu hal yang lain.

Berdasarkan latar belakang yang telah diuraikan sebelumnya, maka rumusan masalah dalam penelitian adalah: apakah pria memiliki Obsession, Power, Budget, Achievement, Anxiety, Evaluation, dan Retention yang lebih besar daripada wanita. Berdasarkan rumusan masalah yang telah diuraikan sebelumnya, maka tujuan penelitian adalah untuk mengetahui apakah pria memiliki Obsession, Power, Budget, Achievement, Anxiety, Evaluation, dan Retention yang lebih besar daripada wanita.

\section{TINJAUAN PUSTAKA Definisi Gender}

Robb dan Sharpe (2011) mengungkapkan jika jenis kelamin adalah suatu karakteristik yang membedakan antara pria dan wanita dalam berperilaku keseharian. pria lebih memainkan pada logika dan naluri yang dimilikinya, sedangkan wanita lebih memainkan 
pada perasaan emosional dalam memutuskan hal di depannya. Echols dan Sadhily (1983) gender adalah perbedaan yang tampak antara pria dan wanita apabila dilihat dari nilai dan tingkah laku. Sedangkan menurut Lips (1988) dalam buku berjudul Sex and Gender mengungkapkan jika gender adalah sebagai harapan budaya terhadap pria dan wanita seperti contoh pria bermain dengan rasional sedangkan wanita bermain dengan emosional tetapi sifat dari gender dapat berubah berdasarkan lingkungan. Barber dan Odean (2001) menjelaskan jika kaum pria lebih berani dalam mengambil resiko daripada kaum wanita hal ini disebabkan oleh faktor psikologis di mana pria tampak lcenderung mencari resiko (risk seeker) dan wanita menghindari resiko di depannya (risk averter).

\section{Pengaruh Antar Variabel}

Lim dan Teo (1997) mengungkapkan jika kaum pria cenderung menganggap uang salah satu tujuan utama hidupnya, mahasiswa Singapura menganggap waktu adalah uang dan waktu adalah sangat berharga, dengan uang dapat berfantasi untuk melakukan apa saja yang diinginkan dengan uang yang dimilikinya. Dosco dan Rosci (2000) serta Rinaldi dan Giromini (2002) mengemukakan jika pria menganggap uang sebagai segala sesuatu yang dapat membuat pribadi bahagia. Zelizer (1989) menggungkapkan meski wanita dalam berumah tangga yang bekerja merupakan sebuah supplemen tambahan untuk pemasukan bagi keluarga yang digunakan untuk membayar tagihan kewajiban seperti keperluan anak, beban listrik dan air, dan pakaian sementara sang suami yang harus berkerja untuk menghidupi keluarga karena suami adalah sebagai kepala keluarga oleh sebab itu sang pria selalu berpikir tentang uang, bagaimana cara mendapatkan uang. Hal ini didukung oleh penelitian Furhan (1984) yang menggungkapkan jika pria lebih terobsesi terhadap uang dari pada wanita. Berbeda dengan penelitian Lim et al., (2003) mengemukakan dalam penelitian jika wanita menganggap uang sebagai hal utama. Sepaham dengan Falahati dan Paim (2011) yang juga mengemukakan hasil penelitian yang menyebutkan wanita lebih menganggap uang sebagai alat obsession.

Lim dan Teo (1997) mengungkapkan jika pria dan wanita hampir mendekati nilai perspektif yang sama dalam menilai uang sebagai kekuatan untuk melekatkan satu dengan lain (lebih banyak teman) tetapi pria lebih menganggap uang sebagai alat kekuatan, hal ini juga didukung oleh Rinaldi dan Todesco (2012), Furnham et al., (2014), Prince (1993), Tang (1993), Falahati dan Paim (2011), Bailey dan Gustafson (1986), Tang dan Gilbert (1995), Li et al., (2015) dan Rabow dan Newcomb (1999) yang juga mengungkapkan hal serupa. Lim et al., (2003) mengemukakan jika pria cenderung menganggap uang sebagai power dari pada kaum wanita. Rinaldi dan Todesco (2012) juga berpendapat sama dari hasil penelitian jika pria cenderung lebih materialistik. Dosco dan Rosci (2000) serta Rinaldi dan Giromini (2002) mengemukakan jika pria menganggap uang sebagai kekuatan bagi individu untuk hidup. Berbeda dengan penelitian Tang dan Chiu (2003) yang mengungkapkan sebaliknya, wanita cenderung menganggap uang sebagai kekuatan dalam perspektif pribadi.

Rinaldi dan Todesco (2012) mengemukakan pria cenderung menganggar keuangan daripada wanita. Rabow dan Newcomb (1999) dan Selcuk (2015) menemukan pria lebih dapat mengontrol diri dalam keuangan. Begitu juga dengan juga Prince (1993) yang mengungkapkan jika wanita cenderung melihat uang sebagai pencapai kepuasan, oleh karena itu wanita menjadi kurang peduli dengan penganggaran keuangan. Berbeda dengan penelitian Tang (1992), menurut hasil penelitian didapatkan wanita lebih memiliki kemampuan untuk menganggarkan keuangan hal ini turut didukung oleh penelitian yang dilakukan oleh Furnham (1984), Lim et al., (2003). Hasil yang didapatkan oleh Dosco dan Rosci (2000) serta Rinaldi dan Giromini (2002) mengemukakan jika wanita lebih menganggar uang untuk kedepannya atau proteksi diri. 
Tang (1993) yang meneliti mengenai achievement terhadap gender di negara Taiwan menemukan jika kaum pria Taiwan lebih mengganggap uang sebagai sebuah achievement daripada wanita, Belsky dan Kobliner (1993) juga mengemukakan hasil penelitian yang menunjukkan jika gaji yang didapatkan oleh seorang pria adalah indikator kesuksesan. Hal ini didukung dengan Lim et al., (2003) mengemukan jika pria menganggap uang adalah simbol kesuksesan seseorang.

Lim dan Teo (1997) mengungkapkan jika kaum pria cenderung menganggap uang sebagai alat perbandingan, mahasiswa Singapura menganggap dengan penganggapan uang sebagai perbandingan maka dapat memberikan sebuah perasaan tertentu setelah berhasil merasa dapat membelanjakan uang untuk barang yang lebih mewah. Argumen ini didukung oleh Rinaldi dan Todesco (2012), Croson dan Gneezy (2009), serta Niederle dan Vesterlund (2011) Berbeda dengan hasil penelitian Lim et al., (2003) mengemukakan jika wanita cenderung menganggap uang sebagai alat evaluasi.

Stinerok et al., (1991) wanita di negara western lebih khawatir terhadap keuangan yang dimiliki daripada pria. penelitian Yeong dan Banerjee (2013), Goldsmith et al., (1997), Belsky dan Kobliner (1993), Rinaldi dan Giromini (2002), serta Funfgeld dan Wang (2008) mengemukakan jika wanita cenderung khawatir dengan uang yang dimiliki daripada pria. Kasus ini juga didukung oleh Lim dan Teo (1997) yang menyatakan bahwa wanita di Singapura lebih khawatir dengan kondisi keuangan yang dimiliki. Berbeda dengan penelitian Lim et al., (2003) dan Falahati dan Paim (2011) mengemukakan pada penelitian, ditemukan jika pria cenderung lebih anxious mengenai keuangan.

Falahati dan Paim (2011) mengemukakan berdasarkan hasil penelitian pria lebih merasa retention, hal ini dikarenakan pria lebih khawatir tentang kondisi keuangan individu dan kesulitan untuk pengambilan keputusan tentang penggunaan uang. Berbeda dengan Lim et al., (2003) dan Li et al., (2015) mengemukakan hasil penelitian yang sebaliknya jika wanita lebih merasa kesulitan dalam memutuskan penggunaan uang.

\section{Perumusan Hipotesis}

Berdasarkan pengaruh antar variabel yang telah disebutkan sebelumnya, maka hipotesis untuk penelitian ini adalah:

$\mathrm{H}_{1}$ : Pria memiliki pandangan Obsession yang lebih besar daripada wanita.

Dalam perilaku keseharian secara umum, pria yang mendapat tanggungjawab sebagai kepala rumah tangga dan menafkahi keluarga, sehingga pria akan mencari uang bagaimanapun caranya. Kemudian, disisi lain sifat pria yang cenderung berpikiran logis, membuat pria selalu melihat kehidupan riil sekarang yang cenderung serba uang, oleh karenanya, kaum pria akan mengganggap uang adalah segalanya.

$\mathrm{H}_{2}$ : Pria memiliki pandangan Power yang lebih besar daripada wanita. Perilaku pria yang berpikiran logis mengenai kehidupan dimana kekuatan dapat menentukan posisi dan harga diri seorang pria.

$\mathrm{H}_{3}$ : Pria memiliki pandangan Budget yang lebih besar daripada wanita.

Untuk menjamin kehidupan pribadi dan keluarga kedepannya yang cukup sulit diprediksi ditambah kehidupan yang serba uang ini, pria akan berupaya menimbun kekayaan dan hanya mencari keperluan yang benar - benar dibutuhkan.

$\mathrm{H}_{4}$ : Pria memiliki pandangan Achievement yang lebih besar daripada wanita.

Semakin tinggi jumlah harta yang dimiliki adalah sebuah kesan kebahagiaan tersendiri, terlebih bagi pria. Jumlah harta besar yang dikumpulkan dengan usaha keras bagi pria akan dirasa lebih sukses jika sekitar mulai memuji dan segan terhadap apa yang telah 
berhasil diraih untuk menjaminkan kehidupannya kelak sebagai penanggungjawab keluarga.

$\mathrm{H}_{5}$ : Pria memiliki pandangan Evaluation yang lebih besar daripada wanita.

Mengantisipasi untuk hal yang tidak diinginkan bagi keluarga adalah salah satu tugas seorang kepala rumah tangga, hal inilah yang juga dipertimbangkan bagi seorang pria. Pria akan melakukan segala perihal untuk mencukupkan kebutuhan pribadi dan keluarga, sehingga juga cenderung melakukan perbandingan antara sekitar dengan yang dimiliki oleh pribadi, seperti contoh tingkat kebahagian hidup yang dimiliki oleh sekitar.

$\mathrm{H}_{6}$ : Pria memiliki pandangan Anxiety yang lebih besar daripada wanita.

Pria cukup sensitif jika seseorang mulai menggali mengenai keuangan yang dimiliki, karena keuangan yang dimiliki oleh pria adalah cermin seberapa mampu menghidupkan keluarga yang akan atau sudah miliki.

$\mathrm{H}_{7}$ : Pria memiliki pandangan Retention yang lebih besar daripada wanita.

Hasrat untuk memiliki sesuatu pasti sering dialami oleh manusia, meski pria harus dapat berpikir bijaksana kedepan tetapi kadang pria ikut tergoda oleh komunitas sekitar, seperti tertarik membeli kemeja baru untuk meningkatkan nilai penampilan, tetapi disisi lain berpikiran bahwa uang untuk membeli kemeja tersebut dapat disimpan untuk hal yang lebih penting kedepan.

\section{METODE PENELITIAN \\ Data Penelitian}

Populasi penelitian yang diteliti adalah penduduk di Kota Batam. Penentuan rancangan sampel yang digunakan dalam penelitian ini didasarkan pada metode purposive sampling, yaitu teknik pengambilan sampel dengan pertimbangan dan kriteria tertentu yang disesuaikan dengan tujuan penelitian. Dasar pengambilan sampel berdasarkan purposive sampling adalah karakteristik anggota sampel yang dapat disesuaikan dengan maksud penelitian. Kriteria pemilihan sampel yang akan diteliti adalah sebagai berikut:

1. Calon responden yang berdomisili atau bertempat tinggal di Kota Batam.

2. Calon responden yang sedang bekerja.

3. Calon responden yang mengolah keuangan pribadi.

4. Calon responden yang berusia di antara 15 sampai dengan 54 tahun.

Untuk mengetahui jumlah sampel berdasarkan kriteria yang telah ditentukan maka menggunakan metode Slovin dalam pengambilan jumlah sampel berdasarkan jumlah populasi yang terdata di dalam rekapan penduduk Batam. Setelah melakukan perhitungan maka didapatkan dari jumlah target responden oleh peneliti (berusia 15 - 54 tahun) sebanyak 121.608 penduduk, maka jumlah kuesioner yang akan disebarkan oleh peneliti minimal berjumlah 399 responden dan untuk mengantisipasi hal yang tidak diinginkan dikedepannya maka jumlah kuesioner ditambah 101 responden menjadi 500 calon responden.

\section{Variabel dan Definisi Operasional Variabel}

Kelompok Obsession di dalam penelitian ini merupakan variabel independen yang artinya kelompok individu yang beranggapan jika uang adalah tujuan utama dari hidup sehingga individu yang berada dalam kelompok ini selalu beranggapan uang adalah segalanya dan akan melakukan apapun demi melegalkan uang, tidak sedikit individu beranggapan jika uang mampu membeli kebahagian, sehingga individu tersebut mendapatkan kebahagiaan melalui pemenuhan hasrat keinginan (Lim \& Teo, 1997). Pengukuran variabel Obsession menggunakan kuesioner terdiri dari 4 (empat) pertanyaan dengan menggunakan skala Likert 
yang dimulai dari sangat tidak setuju (1), tidak setuju (2), cukup setuju (3), setuju (4) dan sangat tidak setuju (5).

Kelompok Power di dalam penelitian ini merupakan variabel independen yang artinya kelompok individu yang beranggapan bahwa uang adalah sumber kekuatan untuk dapat membantu atau mempengaruhi orang lain (Lim \& Teo, 1997). Pengukuran variabel power menggunakan kuesioner terdiri dari 4 (empat) pertanyaan dengan menggunakan skala Likert yang dimulai dari sangat tidak setuju (1), tidak setuju (2), cukup setuju (3), setuju (4) dan sangat tidak setuju (5).

Kelompok Budget di dalam penelitian ini merupakan variabel independen yang artinya kelompok individu yang lebih menyukai menyimpan uang daripada membelanjakan karena akan menggunakannya untuk perihal yang benar - benar diperlukan dan akan mencoba menawarkan dengan tawaran harga yang terbaik untuk individu tersebut (Lim \& Teo, 1997). Pengukuran variabel budget menggunakan kuesioner terdiri dari 4 (empat) pertanyaan dengan menggunakan skala Likert yang dimulai dari sangat tidak setuju (1), tidak setuju (2), cukup setuju (3), setuju (4) dan sangat tidak setuju (5).

Kelompok Achievement di dalam penelitian ini merupakan variabel independen yang artinya kelompok individu yang menganggap uang adalah sebuah simbol kesuksesan seperti contoh gaji dan pendapatan yang individu miliki sekarang, karena gaji dan pendapatan adalah hasil dari kemampuan individu miliki (Lim \& Teo, 1997). Pengukuran variabel achievement menggunakan kuesioner terdiri dari 3 (tiga) pertanyaan dengan menggunakan skala Likert yang dimulai dari sangat tidak setuju (1), tidak setuju (2), cukup setuju (3), setuju (4) dan sangat tidak setuju (5).

Kelompok Evaluation di dalam penelitian ini merupakan variabel independen yang artinya kelompok individu yang menganggap uang sebagai alat standar perbandingan terhadap hal tertentu (Lim \& Teo, 1997). Pengukuran variabel evaluasi menggunakan kuesioner terdiri dari 2 (dua) pertanyaan dengan menggunakan skala Likert yang dimulai dari sangat tidak setuju (1), tidak setuju (2), cukup setuju (3), setuju (4) dan sangat tidak setuju (5).

Kelompok Anxiety di dalam penelitian ini merupakan variabel independen yang artinya kelompok individu yang selalu merasa khawatir dan cemas ketika ditanya mengenai keuangan yang dimiliki, Invididu ini cenderung akan rendahdiri ketika sekitarnya mempunyai jumlah uang yang lebih besar (Lim \& Teo, 1997). Pengukuran variabel Anxiety menggunakan kuesioner terdiri dari 3 (tiga) pertanyaan dengan menggunakan skala Likert yang dimulai dari sangat tidak setuju (1), tidak setuju (2), cukup setuju (3), setuju (4) dan sangat tidak setuju (5).

Kelompok Retention di dalam penelitian ini merupakan variabel independen yang artinya kelompok individu yang cenderung sulit untuk mengambil keputusan apakah akan menyimpan uang atau sebaliknya, (Lim \& Teo, 1997). Pengukuran variabel Retention menggunakan kuesioner terdiri dari 2 (dua) pertanyaan dengan menggunakan skala Likert yang dimulai dari sangat tidak setuju (1), tidak setuju (2), cukup setuju (3), setuju (4) dan sangat tidak setuju (5).

\section{Teknik Pengumpulan Data}

Pada penelitian ini, data yang diambil adalah data primer dan data sekunder. Data primer adalah data yang diperoleh langsung dari lapangan dengan metode pemberian kuesioner yang secara langsung kepada responden. Secara garis besar, kuesioner yang diberikan terdiri dari dua sub bab, yaitu; (1) Pertanyaan umum, yang dimaksudkan untuk mengetahui identitas latar belakang responden. Pertanyaan umum terbagi menjadi 4 (empat) bagian, yaitu mengenai jenis kelamin, usia, jenjang pendidikan, dan pendapatan yang diperoleh. (2) Pertanyaan utama, yang dimaksudkan untuk memperoleh data responden 
mengenai sifat psikologi perilaku keuangan yang berkaitan dengan obsession, power, budget, achievement, evaluation, anxiety, dan retention.

Sedangkan data sekunder didapatkan oleh peneliti melalui halaman web yang disediakan oleh Dinas Kependudukan dan Pencatatan Sipil Kota Batam yang menyediakan informasi mengenai jumlah penduduk yang bertempat tinggal di Kota Batam. Data yang berhasil dikumpulkan akan diproses dengan menggunakan aplikasi perangkat lunak SPSS (Statis Package for the Social Science) versi 21 dengan tahapan uji statistik deskriptif, uji outlier, uji kualitas data (validitas dan reliabilitas), uji asumsi klasik (uji normalitas, uji multikolinieritas, dan uji heteroskedastisitas), dan uji hipotesis (uji F, uji komparatif, dan uji koefisien determinasi).

\section{Metode Analisis Data}

Metode analisa data yang digunakan adalah regresi berganda (multiple regressions). Metode ini digunakan untuk menguji pengaruh satu variabel terikat (dependent variable) dengan variabel bebas (independent variable) yang lebih dari satu (Indriantoro \& Supomo, 2013).

\section{HASIL DAN PEMBAHASAN}

\section{Statistik Deskriptif Demografi Responden}

Pengumpulan data dilakukan dari bulan Maret sampai bulan September 2015. Sebanyak 500 set kuesioner yang disebarkan dengan jumlah pengembalian 471 kuesioner. Berdasarkan kuesioner yang dibagikan, hanya 420 set yang dapat digunakan tetapi jumlah kuesioner tersebut yang akan ditelaah lebih dalam telah memenuuhi kriteria minimal jumlah sample yang diperlukan dalam penelitian ini yaitu 399 lembar angket. Rincian 420 lembar angket yang telah memenuhi kriteria adalah sebagai berikut; 8 kuesioner yang tidak diisi dengan lengkap dalam menjawab pertanyaan kuesioner, 21 kuesioner yang tidak dikembalikan kepada peneliti, dan 51 kuesioner yang terkena outlier.

Tabel 1 menunjukan distribusi frekuensi responden menurut jenis kelamin berdasarkan sampel bahwa pria dan wanita yang sedang bekerja di Kota Batam masing masing berjumlah 215 dan 205 dengan tingkat persentase 51,2\% dan 48,8\%.

\section{Tabel 1. Data Responden Berdasarkan Jenis Kelamin}

\begin{tabular}{lcc}
\hline Jenis Kelamin & Jumlah & Persentase \\
\hline Pria & 215 & 51.2 \\
Wanita & 205 & 48.8 \\
\hline Total & 420 & 100 \\
\hline
\end{tabular}

Tabel 2 menunjukkan hasil pengujian frekuensi responden menurut usia. Dari hasil pengujian didapatkan bahwa sebagian besar responden berada pada kelompok usia 17 - 27 tahun $(86,7 \%)$ dari jumlah keseluruhan responden.

Tabel 2. Data Responden Berdasarkan Usia

\begin{tabular}{lcc}
\hline \multicolumn{1}{c}{ Kategori Usia } & Jumlah & Persentase \\
\hline $17-27$ tahun & 364 & 86.7 \\
$28-40$ tahun & 55 & 13.1 \\
$41-55$ tahun & 1 & 0.2 \\
\hline Total & 420 & 100 \\
\hline
\end{tabular}


Tabel 3 menunjukan frekuensi responden berdasarkan status pendidikannya. Dari hasil tabulasi frekuensi diperoleh kesimpulan bahwa responden terdiri dari sebagian besar berstatus pendidikan S1 sebanyak $348(82,9 \%)$ dan SMA/K sebanyak $47(11,2 \%)$ disusul dengan Diploma sebanyak $15(3,6 \%)$ responden, SMP sebanyak $4(1,0 \%)$ responden, SD sebanyak 5 $(1,2 \%)$, dan dibawah SD sebanyak $1(0,2 \%)$ responden.

Tabel 3. Data Responden Berdasarkan Status Pendidikan

\begin{tabular}{lcc}
\hline \multicolumn{1}{c}{ Pendidikan } & Jumlah & Persentase \\
\hline S SD & 1 & 0,2 \\
SD & 5 & 1,2 \\
SMP & 4 & 1,0 \\
SMA/K & 47 & 11,2 \\
Diploma & 15 & 3,6 \\
S1 & 348 & 82,9 \\
\hline Total & 420 & 100 \\
\hline
\end{tabular}

Tabel 4 menunjukkan frekuensi responden berdasarkan tingkat pendapatan perbulan. Diperoleh kesimpulan bahwa terdapat 289 responden $(68,8 \%)$ memiliki tingkat pendapatan sebesar Rp 2.000,000,00 - Rp 4.000,000,00. Sebanyak 106 responden (25,2\%) memiliki tingkat pendapatan dibawah Rp 2.000.000,00 dan sebanyak 25 responden $(6,0 \%)$ memiliki tingkat pendapatan di atas Rp 4.000.000,00.

Tabel 4. Data Responden Berdasarkan Pendapatan (Rupiah)

\begin{tabular}{lcc}
\hline \multicolumn{1}{c}{ Kategori Pendapatan } & Jumlah & Persentase \\
\hline$<2.000 .000$ & 106 & 25,2 \\
$2.000 .000-4.000 .000$ & 289 & 68,8 \\
$>4.000 .000$ & 25 & 6,0 \\
\hline Total & 420 & 100 \\
\hline
\end{tabular}

\section{Hasil Uji Outlier}

Dari hasil analisis uji outlier dengan melihat nilai z-score yang dimiliki dari setiap responden dalam menjawab pertanyaan masing-masing secara pribadi maka peneliti mendapatkan sejumlah variabel mengalami penyimpangan yaitu sebanyak 51 data yang mengalami outlier. Semua nilai z-score yang dipilih oleh peneliti merupakan data yang tersebar diantara nilai kritis -1,96 dan 1,96.

\section{Hasil Uji Kualitas Data Uji Validitas}

Berdasarkan hasil data yang diujikan, semua variabel yang ditelaah menunjukkan hasil valid karena nilai muatan faktor yang diberikan berada pada posisi lebih dari poin 0,55. 
Tabel 5. Hasil Uji Validitas

\begin{tabular}{lcc}
\hline Pertanyaan & Muatan Faktor & Keterangan \\
\hline Obsession 1 & 0.795 & Valid \\
Obsession 2 & 0.833 & Valid \\
Obsession 3 & 0.792 & Valid \\
Obsession 4 & 0.829 & Valid \\
Power 1 & 0.741 & Valid \\
Power 2 & 0.790 & Valid \\
Power 3 & 0.838 & Valid \\
Power 4 & 0.748 & Valid \\
Budget 1 & 0.738 & Valid \\
Budget 2 & 0.745 & Valid \\
Budget 3 & 0.780 & Valid \\
Budget 4 & 0.671 & Valid \\
Achievement 1 & 0.743 & Valid \\
Achievement 2 & 0.771 & Valid \\
Achievement 3 & Valid \\
Evaluation 1 & 0.788 & Valid \\
Evaluation 2 & 0.698 & Valid \\
Evaluation 3 & 0.834 & Valid \\
Anxiety 1 & 0.837 & Valid \\
Anxiety 2 & 0.649 & Valid \\
Anxiety 3 & 0.782 & Valid \\
Retention 1 & 0.692 & Valid \\
Retention 2 & 0.795 & Valid \\
\hline
\end{tabular}

\section{Uji Reliabilitas}

Hasil pengujian dapat terlihat bahwa seluruh variabel adalah reliabel dilihat dari nilai cronbach alpha > 0,50 (Hair, et al., 2010). Sehingga dapat disimpulkan kuesioner yang digunakan dalam penelitian ini merupakan kuesioner yang handal.

Tabel 6. Hasil Uji Reabilitas

\begin{tabular}{lcc}
\hline \multicolumn{1}{c}{ Variabel } & Alpha $(\boldsymbol{\alpha})$ & Keterangan \\
\hline Obsession & 0.825 & Reliabel \\
Power & 0.782 & Reliabel \\
Budget & 0.708 & Reliabel \\
Achievement & 0.650 & Reliabel \\
Evaluation & 0.699 & Reliabel \\
Anxiety & 0.539 & Reliabel \\
Retention & 0.560 & Reliabel \\
\hline
\end{tabular}

\section{Hasil Uji Asumsi Klasik}

\section{Hasil Uji Normalitas}

Pada tabel 7 menunjukkan hasil penelitian normalitas, penelitian yang menggunakan pendekatan metode kolmogorov smirnov maka didapatkan nilai 0.168 , dengan demikian dapat menyimpulkan bahwa pengaruh antara variabel independen yaitu obsession, power, budget, 
achievement, evaluation, anxiety, dan retention terdistribusi secara normal karena hasil pengujian yang didapatkan berada di atas 0.05 .

Tabel 7. Hasil Uji Normalitas

\begin{tabular}{cc}
\hline Model & Standardized Residual \\
\hline Asymp. Sig (2-tailed) & 0.168 \\
\hline
\end{tabular}

\section{Hasil Uji Multikolinieritas}

Hasil uji multikolinieritas untuk model regresi ini disajikan dalam Tabel 8 Berdasarkan hasil penelitian terhadap nilai VIF variabel independen untuk model regresi berada dibawah 10 dan nilai tolerance berada diatas nilai 0,1 Oleh karena itu, dapat disimpulkan bahwa tidak terjadi multikolinieritas antar variabel independen pada model regresi tersebut.

Tabel 8. Hasil Uji Multikolinieritas

\begin{tabular}{lccl}
\hline \multicolumn{1}{c}{ Variabel } & Tolerance & VIF & Keterangan \\
\hline Obsession & 0.593 & 1.686 & Tidak Terjadi Multikolinieritas \\
Power & 0.650 & 1.537 & Tidak Terjadi Multikolinieritas \\
Budget & 0.942 & 1.062 & Tidak Terjadi Multikolinieritas \\
Achievement & 0.758 & 1.318 & Tidak Terjadi Multikolinieritas \\
Evaluation & 0.671 & 1.491 & Tidak Terjadi Multikolinieritas \\
Anxiety & 0.784 & 1.276 & Tidak Terjadi Multikolinieritas \\
Retention & 0.854 & 1.171 & Tidak Terjadi Multikolinieritas \\
\hline
\end{tabular}

\section{Hasil Uji Heteroskedastisitas}

Hasil uji heteroskedastisitas dengan Glejser dapat dilihat pada tabel 9 didapatkan jika hasil nilai signifikansi antara variabel independen dengan absolute residual berada lebih dari 0.05, oleh karena itu dapat disimpulkan jika tiap variabel tidak terjadi masalah heteroskedastisitas.

Tabel 9. Hasil Uji Heteroskedastisitas

\begin{tabular}{lll}
\hline \multicolumn{1}{c}{ Variabel } & Sig. & Keterangan \\
\hline Obsession & 0.083 & Homoskedastisitas \\
Power & 0.930 & Homoskedastisitas \\
Budget & 0.052 & Homoskedastisitas \\
Achievement & 0.433 & Homoskedastisitas \\
Evaluation & 0.961 & Homoskedastisitas \\
Anxiety & 0.053 & Homoskedastisitas \\
Retention & 0.060 & Homoskedastisitas \\
\hline
\end{tabular}




\section{Hasil Uji Hipotesis \\ Hasil Uji F}

Berdasarkan hasil model regresi yang tampak pada tabel 10 dalam uji $\mathrm{F}$ diperoleh nilai signifikan berupa 0,000 dengan nilai signifikan lebih kecil dari 0,05, maka dapat disimpulkan jika model regresi yang ditelaah dapat digunakan untuk memprediksi variabel dependen.

\section{Tabel 10. Hasil Uji F}

\begin{tabular}{lll}
\hline Variabel Dependen & F & Sig \\
\hline Gender & 15.266 & 0.000 \\
\hline
\end{tabular}

\section{Hasil Uji Komparatif}

Tabel 11 di atas menunjukkan hasil perhitungan uji komparatif dari variabel independen terhadap variabel dependen dengan pengamatan melalui mean untuk memperlihatkan perbandingan pandangan antar gender (pria dan wanita) dalam menyikapi perilaku keuangan.

Tabel 11. Hasil Uji Komparatif

\begin{tabular}{llcc}
\hline \multicolumn{1}{c}{ Variabel } & Jenis Kelamin & Mean & Keterangan \\
\hline Obsession & Pria & 13.012 & Lebih tinggi \\
\multirow{3}{*}{ Power } & Wanita & 11.454 & Lebih rendah \\
& Pria & 12.428 & Lebih tinggi \\
Budget & Wanita & 11.644 & Lebih rendah \\
& Pria & 14.284 & Lebih tinggi \\
Achievement & Wanita & 13.878 & Lebih rendah \\
\multirow{2}{*}{ Evaluation } & Pria & 10.721 & Lebih tinggi \\
& Wanita & 10.356 & Lebih rendah \\
Anxiety & Pria & 10.246 & Lebih tinggi \\
& Wanita & 8.268 & Lebih rendah \\
Retention & Pria & 8.405 & Lebih rendah \\
& Wanita & 8.668 & Lebih tinggi \\
& Pria & 5.818 & Lebih rendah \\
\hline
\end{tabular}

H1: Pria memiliki pandangan obsession yang lebih besar mengenai keuangan daripada wanita.

Variabel obsession yang diteliti oleh peneliti dalam menganalisis perbandingan pandangan antar gender didapatkan jika pria lebih merasa obsession dalam melihat uang. Pria adalah calon kepala rumah tangga di masa depan yang akan memiliki rasa sebuah kewajiban untuk memenuhi kehidupan keluarganya dikedepannya, hal inilah menjadi alasan pria selalu mencari uang (Rinaldi \& Giromini, 2002). Hasil Peneltian ini juga sependapat dengan Lim dan Teo (1997), Dosco dan Rosci (2000), Zelizer (1989), serta Furhan (1984).Tetapi hasil penelitian ini tidak sejalan dengan Lim, et al., (2003) dan Falahati dan Paim (2011) yang mengemukakan hal sebaliknya jika wanita menganggap uang sebagai hal utama. 
H2: Pria memiliki pandangan power yang lebih besar mengenai keuangan daripada wanita.

Variabel power yang diteliti oleh peneliti dalam menganalisis perbandingan pandangan antar gender didapatkan jika pria lebih menganggap uang sebagai power dalam melakukan transaksi keuangan. Anggapan pria mengaggap uang sebagai sumber yang berharga karena dapat menjadikan pribadi yang memiliki kepercayaan diri tinggi dan otoritas dalam melakukan hubungan dengan sekitar (Lim \& Teo,1997). Hasil Peneltian ini sependapat dengan Rinaldi dan Todesco (2012), Furnham, et al. (2014), Prince (1993), Tang (1993), Falahati dan Paim (2011), Bailey dam Gustafson (1986), Tang dan Gilbert (1995), Rabow dan Newcomb (1999), Lim, et al. (2003), dan Dosco dan Rosci (2000), serta Li, et al., (2009). Tetapi hasil penelitian ini berbeda dengan hasil Tang (2003) yang mengungkapkan sebaliknya, wanita lebih cenderung menganggap uang sebagai kekuatan dalam perspektif pribadi.

H3: Pria memiliki pandangan budget yang lebih kecil mengenai keuangan daripada wanita.

Variabel budget yang diteliti oleh peneliti dalam menganalisis perbandingan pandangan antar gender didapatkan jika pria lebih mampu mengatur keuangan pribadi dalam menggunakan uang. Pria lebih mampu mengatur keuangan karena memiliki pemikiran untuk membayar kewajiban tepat waktu dan menyimpan sebagian uang untuk kehidupan masa depan yang akan dihadapi (Selcuk, 2015). Peneliti terdahulu yang mengungkapkan jika pria lebih mampu menganggar keuangan yang dimiliki adalah Prince (1993), Rabow dan Newcomb (1999),dan Rinaldi dan Todesco (2012). Berbeda dengan Furnham (1984), Tang (1992), Dosco dan Rosci (2000), Lim et al., (2003), serta Rinaldi dan Giromini (2002) yang mengungkapkan wanita lebih memiliki kemampuan untuk menganggarkan keuangan.

H4: Pria memiliki pandangan achievement yang lebih besar mengenai keuangan daripada wanita.

Variabel achievement yang diteliti oleh peneliti dalam menganalisis perbandingan pandangan antar gender didapatkan jika pria lebih menganggap uang sebagai sebuah achievement. Pria lebih memperhatikan keuangan yang dimiliki karena sebagai calon kepala keluarga sehingga perlu kerja keras untuk mencari uang demi masa depan, sehingga uang yang didapatkan dengan jerih payah inilah sebagai sebuah penghargaan atas kerja keras (Lim et al., 2003). Hasil Peneltian ini sejalan dengan Tang (1993) dan Belsky dan kobliner (1993).

H5: Pria memiliki pandangan evaluation yang lebih kecil mengenai keuangan daripada wanita.

Variabel evaluation yang diteliti oleh peneliti dalam menganalisis perbandingan pandangan antar gender didapatkan jika pria lebih menyukai untuk mengevaluasi keuangan yang diminilikinya. Sebagai calon kepala keluarga, seorang pria perlu mengevaluasi jumlah dana yang dimiliki dan mengatur urusan keuangan sebaik mungkin untuk kedepannya sehingga kebutuhan keluarga kedepannya terpenuhi (Lim \& Teo, 1997). Hasil Peneltian yang mengungkapkan jika pria lebih mampu mengevaluasi keuangan yang dimiliki sejalan dengan hasil penelitian oleh Rinaldi dan Todesco (2012), Croson dan Gneezy (2009), serta Niederle dan Vesterlund (2011) dan tidak sejalan dengan Lim, et al., (2003).

H6: Pria memiliki pandangan anxiety yang lebih kecil mengenai keuangan daripada wanita.

Variabel anxiety yang diteliti oleh peneliti dalam menganalisis perbandingan pandangan antar gender didapatkan jika wanita lebih merasa merasa anxious dalam menggunakan uang. Wanita lebih merasa cemas karena sifat emosional yang dimiliki oleh individu saat melihat 
sisa uang yang dimiliki setelah membayar keperluan lain, hal ini dikarenakan sifat wanita yang kurang dapat menahan godaan seperti mengenai berbelanja karena hanya adanya potongan harga (Yeong \& Banarjee, 2013). Hasil Penelitian ini juga didukung oleh Stinerok, et al., (1991), Goldsmith, et al., (1997), Belsky dan Kobliner (1993), Lim dan Teo (1997), serta Funfgeld dan Wang (2009) tetapi berbeda dengan dengan hasil penelitian Lim, et al., (2003) dan Falahati dan Paim (2011).

H7: Pria memiliki pandangan retention yang lebih kecil mengenai keuangan daripada wanita.

Variabel retention yang diteliti oleh peneliti dalam menganalisis perbandingan pandangan antar gender didapatkan jika wanita lebih merasa retention dalam menggunakan uang. Karena sifat emosional yang dimiliki wanita meski telah merincikan apa yang harus dilakukan masa depan maka sedikit sulit untuk memutuskan menggunakan uang atau tidak ketika menemukan suatu hal yang menarik di depan mata, karena harus mempertimbangkan keperluan nanti dan perihal yang menarik di depan mata sekarang (Lim et al., 2003). Hasil Peneltian ini sejalan dengan hasil penelitian oleh Li et al., (2009) tetapi hal ini berbeda padangan kepada Falahati dan Paim (2011).

\section{Hasil Uji Koefisien Determinasi $\left(\mathbf{R}^{2}\right)$}

Pada tabel hasil uji koefisien determinasi di bawah, nilai koefisien determinasi untuk model regresi adalah 0,460 yang berarti bahwa 46,0\% variabel keputusan penggunaan uang berdasarkan gender dapat dijelaskan oleh obsession, power, budget, achievement, evaluasi, anxiety, dan retention. Sedangkan sisanya sebesar 54,0\% dapat dijelaskan oleh faktor lain di luar model.

\section{Tabel 12. Hasil Uji Koefisien Determinasi $\left(\mathbf{R}^{2}\right)$}

\begin{tabular}{cc}
\hline $\mathbf{R}^{\mathbf{2}}$ & Adjusted R Square \\
\hline 0.492 & 0.460 \\
\hline
\end{tabular}

\section{SIMPULAN}

Dalam penelitian mengenai perbedaan persepsi sifat psikologi keuangan (obsession, power, budget, achievement, evaluasi, anxiety, dan retention) antar gender di Kota Batam. Berdasarkan hasil analisis dan pembahasan yang dilakukan dalam bab sebelumnya dapat diperoleh kesimpulan bahwa:

1. Kaum pria memiliki pandangan obsession yang lebih besar mengenai keuangan daripada wanita. Hasil Peneltian ini konsisten dengan Lim dan Teo (1997), Dosco dan Rosci (2000), Rinaldi dan Giromini (2002), Zelizer (1989), dan Furhan (1984) tetapi berbeda pandangan kepada Lim et al., (2003) serta Falahati dan Paim (2011).

2. Kaum pria memiliki pandangan power yang lebih besar mengenai keuangan daripada wanita. Hasil Peneltian ini konsisten dengan Lim dan Teo (1997), Rinaldi dan Todesco (2012), Furnham et al. (2014), Prince (1993), Tang (1993), Falahati dan Paim (2011), Bailey dam Gustafson (1986), Tang dan Gilbert (1995), Rabow dan Newcomb (1999), Lim et al. (2003), dan Dosco dan Rosci (2000), serta Li et al., (2009), tetapi berbeda pandangan kepada Tang (2003).

3. Kaum pria memiliki pandangan budget yang lebih besar mengenai keuangan daripada wanita. Hasil Peneltian ini konsisten dengan Rinaldi dan Todesco (2012), Rabow dan Newcomb (1999), Prince (1993), serta Selcuk (2015), tetapi berbeda pandangan Tang 
(1992), Furnham (1984), Lim et al., (2003), Dosco dan Rosci (2000) serta Rinaldi dan Giromini (2002).

4. Kaum pria memiliki pandangan achievement yang lebih besar mengenai keuangan daripada wanita. Hasil Peneltian ini konsisten dengan Tang (1993), Belsky dan kobliner (1993), dan Lim et al., (2003).

5. Kaum pria memiliki pandangan evaluation yang lebih besar mengenai keuangan daripada wanita. Hasil Peneltian ini konsisten dengan Lim dan Teo (1997), Rinaldi dan Todesco (2012), Croson dan Gneezy (2009), dan Niederle dan Vesterlund (2011), tetapi hal ini berbeda pandagan kepada Lim et al., (2003).

6. Kaum wanita memiliki pandangan anxiety yang lebih besar mengenai keuangan daripada pria. Hasil Peneltian ini konsisten dengan Stinerok et al., (1991), Yeong dan Banerjee (2013), Goldsmith et al., (1997), Belsky dan Kobliner (1993), Lim dan Teo (1997), Rinaldi dan Giromini (2002), serta Funfgeld dan Wang (2009), tetapi hal ini berbeda pandangan kepada Lim et al., (2003) serta Falahati dan Paim (2011).

7. Kaum wanita memiliki pandangan Retention yang lebih besar mengenai keuangan daripada pria. Hasil Peneltian ini konsisten dengan Lim et al., (2003) dan Li et al., (2009), tetapi hal ini berbeda padangan kepada Falahati dan Paim (2011).

Dalam melakukan penelitian ini, terdapat beberapa keterbatasan yang mengakibatkan kurang sempurnanya penelitian ini, diantaranya:

1. Dikarenakan keterbatasan waktu penelitian, maka jumlah responden yang diperoleh sebatas 500 responden.

2. Adanya keterbatasan data pendukung mengenai sifat psikologi keuangan dengan variabel yang diharapkan untuk dikaji.

3. Terdapatnya variabel lain di luar variabel yang dikaji oleh peneliti (obsession, power, budget, achievement, evaluasi, anxiety, dan retention) yang mempengaruhi keputusan penggunaan uang.

Dilihat dari kesimpulan dan keterbatasan yang ada, maka saran dan bahan pertimbangan yang dapat digunakan sebagai bahan masukan dan pertimbangan bagi penelitian selanjutnya adalah:

1. Penambahan variabel lain untuk memperkuat penganalisaan mengenai psikologi keuangan, seperti: financial literacy (Masuo, et al., 2004; Rinaldi \& Todesco, 2012; Selcuk, 2015) dan socio-economic (Furnham, et al., 2014; Mellan, 1994).

2. Perluasan kelompok yang menjadi sampel penelitian sehingga mengetahui perbedaan perilaku keuangan antar kelompok.

\section{DAFTAR PUSTAKA}

Bailey, W. C. \& Gustafson, A. W. 1986. Gender and Gender Role Orientation Differences in Attitudes and Behaviors Toward Money. Proceedings. Presented at the fourth Annual Conference of the Association for Financial Conseling Planning and Education. 11 20.

Barber, B \& Odean T. 2001. Boys will be Boys: Gender, Overconfidence, and Common Stock Investment. Quarterly Journal of Economics. 261-292.

Belsky, G. \& Kobliner, B. 1993. He Says, She Says: How Men and Women Differ About Money. $76-84$.

Clave, M. \& Sincich. 2003. Statistics 9th ed. New Jersey: Prentice Hall.

Croson, R. \& Gneezy U. 2009. Gender Differences in Preferences. Journal of Economic Literature. $448-478$. 
Novendy Arifin Dan Robin: Analisis Perbedaan Persepsi Psikologi Keuangan Antara Pria Dan Wanita Di Kota Batam

Durvasula, S. \& Lysonski, S. 2010. Money, Money, Money - How do Attitudes Toward Money Impact Vanity and Materialism? - the Case of Young Chinese Consumers. Journal of Consumer Marketing. 27(2).169-179.

Dosso, C., \& Rosci, E. 2000. Gli adolescenti e l'uso del denaro (Adolescent and Money Attitude).

Echols, J. M. dan Shadily H. 1944. The People of Alor. New York: Harper \& Brothers.

Falahati, L. \& Paim, L. H. 2011. A comparative study in Money Attitude among University Students: A Gendered View. Journal of American Science.1144-1148.

Funfgeld, B. \& Wang, M. 2009. Attitudes and behaviour in everyday finance: evidence from Switzerland. International Journal of Bank Marketing. 27 (2). 108-128.

Furnham, A. 1984. Many Sides of the Coin: The Psychology of Money Usage. Personality and Individual Differences. 501-509

Furnham A., Stumm S., \& O’Creevy M.F. 2014. Sex Differences in Money Pathology in the General Population.

Ghozali, Imam. 2011. Aplikasi Analisis Multivariate dengan Proram SPSS. Cetakan Pertama. Semarang: Badan Penerbit Universitas Dipenogoro.

Goldsmith, R.E. \& Goldsmith E.B. 1997. Gender Differences in Perceived and Real Knowledge of Financial Investments. Journal of Psychological Reports. 236-238.

Gujarati, Damodar \& Porter, D. C. 2009. Basic Econometrics. Boston: Mc Graw - Hill.

Handi, A. K. \& Mahastanti, L. A. 2012. Perilaku Penggunaan Uang: Apakah Berbeda Untuk Jenis Kelamin dan Kesulitan Keuangan.

Hair, J.F., Anderson R.E, Tatham R.L, \& Black W.C. 2010. Multivariate Data Analysis with Readings. $7^{\text {th }}$ Edition. New Jersey: Prentice Hall, Englewood Cliffs.

Hibbert, S., Smith, A., Davies, A. \& Ireland, F. 2007. Guilt Appeals: Persuasion Knowledge and Charitable Giving. Psychology and Marketing. Page 723- 742.

Lips, H. M. 1988. Sex \& Gender : An Introduction Hilary M. Lips . $2^{\text {nd }}$ Edition.

Indriantoro, N., \& Supomo, B. 2013. Metodologi Penelitian Bisnis Untuk Akuntansi dan Manajemen. Edisi Pertama Cetakan Keenam. Yogyakarta: BPFE. Page 85-186.

Li, D., Jiang, Y., An S., Shen, Z., \& Jin, W. 2009. The Influence of Money Attitudes on Young Chinese consumers' compulsive. Vol. 10 No. 2. Page 98-109.

Lim, V. K. G., \& Teo, T. S. H. 1997. Sex, money and financial hardship: an empirical study of attitudes towards money among undergraduates in Singapore. Journal of Economic Psychology. 369-386.

Lim V. K. G., Teo T. S. H., \& Loo, G. 1. 2003. Sex, Financial Hardship and Locus of Control: an Empirical Study of Attitudes Towards Money Among Singaporean Chinese. Journal of Personality and Individual Differences. 411-429

Margono. 2010. Metodologi Penelitian Pendidikan. Jakarta: Rineka Cipta.

Masuo, D. M., Malroutu, Y. L., Hanashiro, R., \& Kim, J. H. 2004. College Students' Money Beliefs and Behaviors: An Asian Perspective . Journal of Family and Economic Issues. 25 (4). 469- 481.

Mellan, O. 1994. Your Money Style. New York: MJF Books.

Niederle, M \& Vesterlund, L. 2011. Gender and Competition. Annual Review in Economics. $601-630$.

Prince, Melvin. 1995. Gender and Money Attitude of Young Adults.

Fordham University.Rabow, J. \& Newcomb, M. D. (1999). Gender, Socialization, and Money. Journal of Applied Social Psychology. 852 - 869.

Rinaldi, E., \& Giromini, E. 2002. The importance of money to Italian children. Young Consumers.(3) $53-59$. 
Rinaldi, E., \& Todesco, L. 2012. Financial Literacy and Money Attitudes: Do Boys and Girls Really Differ? A Study among Italian Preadolescents. Italian Journal of Sociology of Education $2^{\text {th }} .143-165$.

Robb, C. and Sharpe, D. L. 2009. Effect of Personal Financial Knowledge on College Student's Credit Card Behavior. Jurnal Of Financial And Planing. (20).

Santrock. J. W. 2003. Adolescence: Perkembangan Remaja. Jakarta: Erlangga.

Selcuk, E. A. 2015. Factors Influencing College Students' Financial Behaviors in Turkey: Evidence from a National Survey. International Journal of Economics and Finance (7). $87-94$.

Shefrin, H. \& Meir, S. 2000. Behavioral Portfolio Theory. Journal of Finance and Quantitative Analysis. 127-151.

Stinerock, R., Stern, B. B., \& Solomon M. R. 1991. Sex and Money: Gender Differences in the Use of Surrogate Consumers for Financial Decision - Making. Journal of Professional Services Marketing.

Sugiyono. 2012. Metodologi Penelitian Bisnis. Cetakan 16. Bandung: Alfabeta.

Tang, T. L. P 1992. The meaning of money revisited. Journal of Organizational Behavior. 197-202.

Tang, T. L. P. 1993. The Meaning of Money: Extension and Exploration of the Money Ethic Scale in a Sample of University Students in Taiwan. Journal of Organizational Behavior. 93-99.

Tang, T. L. P. \& Gilbert, P. R. 1995. Attitudes Toward Money as Related to Intrinsic and Extrinsic Job Satisfaction, Stress and Work - Related Attitudes. 327-332.

Tang, T. L. P. \& Chiu, R. K. 2003. Income, Money Ethic, Pay Satisfaction, Commitment, and Unethical Behavior: Is the Love of Money the Root of Evil for Hong Kong Employees?. Journal of Business Ethics. 13 - 30.

Wel, C. A. C., Omar. N. A., Alam S., S., \& Nor. S. M. Exploring Young Adults Attitudes Towards Money.

Yeong, N. C., \& Banarjee, G. Empirical Analysis of Bicultural Border College Students' Attitudes Toward Money. Journal of Applied Business and Economics. (14).70 - 82.

Zelizer, V. A. 1989. The Social Meaning of Money: Special Monies. American Journal of Sociology .95. $342-377$.

Batam. 2014. Rekap Penduduk Menurut Usia Sekolah. Available at: http://kepri.bps.go.id/. 30 Desember 2014.

Batampos. 2015. Gubernur: Pertumbuhan Kepri Dekati Target. Available at:. (http://batampos.co.id/15-06-2015/gubernur-pertumbuhan-ekonomi-kepri-dekati-target/. 27 Oktober 2015. 